\title{
MENGEMBANGKAN KECERDASAN MULTIPLE INTELLEGENCE ANAK USIA DINI
}

\author{
Ardiansyah, Moh. Alamsyah
}

\begin{abstract}
The golden age is a period that cannot be repeated again. This period also determines the life of a human being in the future. When learning there are aspects that experience development, namely cognitive, abstract thinking, creative thinking, social-emotional, motor, language or communication, and can also develop creativity. So from this aspect it can improve the development of children's multiple intelligences. Multiple Intelligences include verbal linguistics, logical-mathematical, visual spatial, musical, kinetic, intrapersonal, interpersonal, naturalist and existential. The purpose of this study is to analyze how multiple intelligences can be developed in early childhood. With this research, parents can recognize the intelligence of children and even direct and develop intelligence to the fullest. This research is a qualitative research with literature study. The results of this study are Multiple Intelligence in the aspect of linguistic intelligence and Interpersonal intelligence is very important to be developed in early childhood, because it becomes a bridge in developing children's intelligence, the development of linguistic intelligence provides communication and socialization skills and expresses children to the outside world, while Interpersonal intelligence provides the ability to manage emotionalsocial so that it becomes a controller for children in thinking and acting towards maturity.
\end{abstract}

\section{Keywords: Multiple Intellegence, Early Childhood}

\section{PENDAHULUAN}

Usia dini merupakan periode awal yang paling penting dan mendasar sepanjang rentang pertumbuhan serta perkembangan kehidupan manusia. Masa ini ditandai oleh berbagai periode penting yang fundamental dalam kehidupan anak selanjutnya sampai periode akhir perkembangannya. Usia dini menurut Peraturan Presiden (Perpres) Nomor 60 Tahun 2013, adalah bayi yang baru lahir hingga anak-anak yang belum genap berusia 6 tahun. 
Periode ini dimana hampir seluruh potensi anak berkembang dengan sangat pesat dan hebat yang sering di sebut dengan "golden age" atau masa emas. Perkembangan setiap anak pada periode ini tidak sama karena setiap individu memiliki perkembangan yang berbeda yang dapat dipengaruhi oleh Makanan yang bergizi seimbang serta stimulasi intensif yang sangat dibutuhkan anak untuk pertumbuhan dan perkembangan tersebut. Pemberian stimulasi atau gizi yang baik pada anak akan membuat proses pertumbuhan dan perkembangan anak akan terjadi secara baik. ${ }^{1}$

Anak usia dini merupakan komunitas anak yang mengalami proses pertumbuhan dan perkembangan yang unik. Pertumbuhan dan perkembangan (koordinasi motorik halus dan kasar) menjadi pola yang dimiliki oleh anak. Begitu pula daya pikir, daya cipta, bahasa dan komunikasi yang tercakup dalam kecerdasan intelektual $(I Q)$, kecerdasan emosional $(E Q)$, dan kecerdasan spiritual $(S Q)$ yang sesuai dengan tingkat perkembangan anak ${ }^{2}$. Periode keemasan tersebut dapat pula disebut sebagai masa imitasi, masa peka, masa eksploitasi dunia baru dan masa bermain.

Pertumbuhan dan perkembangan yang unik pada anak usia dini tersebut secara psikologis memiliki karakteristik yang khas dan berbeda dengan anak yang lebih dewasa dari usianya. Anak usia dini memiliki karakteristik yaitu anak bersifat egosentris, memiliki rasa ingin tahu, bersifat unik, memiliki imajinasi dan fantasi dan anak memiliki daya konsentrasi yang pendek. Potensi ini berkaitan pula dengan kecerdasannya.

Pendidikan memiliki peran penting dalam mengembangkan kecerdasan anak. Pendidikan anak usia dini secara optimal dikembangkan dengan melihat karakteristik yang dimiliki oleh anak sehingga terbentuk perilaku dan kemampuan dasar sesuai dengan tahap perkembangannya. Sebagai makhluk yang paling sempurna, manusia diciptakan memiliki nilai lebih berupa akal (kecerdasan) dan bentuk paling sempurna diantara makhluk ciptaan Allah SWT lainnya sebagaimana diterangkan dalam Surah At-Tin ayat 4 yang artinya:

\footnotetext{
${ }^{1}$ Hasnida, Analisis Kebutuhan Anak Usia Dini, (Jakarta: PT. Luxiama Metro Media, 2014), 169.

${ }^{2}$ Mansur, Pendidikan Anak Usia Dini dalam Islam, (Yogyakarta: Pustaka Pelajar, 2014), 8.
} 
"Sesungguhnya kami telah menciptakan manusia dalam bentuk yang sebaikbaiknya".

Setiap anak diyakini lahir dengan lebih dari satu bakat hal ini berdasarkan teori perkembangan anak. ${ }^{3}$ Pada hakikatnya inteligensi adalah kemampuan yang dibawa sejak lahir, yang memungkinkan seseorang berbuat sesuatu dengan cara tertentu. ${ }^{4}$

Kecerdasan merupakan istilah yang sulit untuk didefinisikan hingga menimbulkan pemahaman yang berbeda-beda diantara para ilmuwan. Kecerdasan seringkali dimaknai sebagai kemampuan memahami sesuatu dan kemampuan berpendapat ${ }^{5}$, dalam hal ini kecerdasan dipahami sebagai kemampuan intelektual yang menekankan logika dalam memecahkan masalah. Definisi lain tentang kecerdasan mencakup kemampuan beradaptasi dengan lingkungan baru atau perubahan lingkungan saat ini, kemampuan untuk mengevaluasi dan menilai, kemampuan untuk memahami ide-ide yang kompleks, kemampuan untuk berpikir produktif, kemampuan untuk belajar dengan cepat, belajar dari pengalaman, dan bahkan kemampuan untuk memahami hubungan. ${ }^{6}$

Kecerdasan dapat dikatakan sebagai salah satu faktor utama yang menentukan sukses atau tidaknya anak saat disekolah. Peserta didik dengan kecerdasan tinggi sering kali di harapkan mendapat prestasi yang baik sedanngkan anak yang memiliki kecerdasan rendah dipersepsikan sukar mendapat prestasi yang tinggi. Jaminan bahwa dengan taraf kecerdasan tinggi seseorang secara otomatis akan sukses belajar disekolah merupakan anggapan yang keliru ${ }^{7}$, sebab Setiap anak terlahir dengan memiliki lebih dari satu kecerdasan yang dimilikinya dan semua itu perlu dikembangkan agar dapat tumbuh dengan baik.

${ }^{3}$ Yuliani Nurani Sujiono, Konsep Dasar Pendidikan Anak Usia Dini. (Jakarta: Indeks, 2012), 54.

${ }^{4}$ Ibid, 177.

${ }^{5}$ Mustaqim, Psikologi Pendidikan, (Semarang: Fakultas Tarbiyah 1AIN Walisongo, 2004), 104.

${ }^{6}$ Yaumi, Muhammad, Pembelajaran Berbasis Multiple Intelligences (Jakarta: PT. Dian Rakyat, 2012), 9-10.

${ }^{7}$ Siskandar, Pengembangan Multiple Intelligences Melalui Kegiatan Non-Intrakurikuler dalam Rangka Meningkatkan Mutu Proses dan Hasil Pembelajaran, (Jurnal Ekonomi \& Pendidikan, Vol. 5, No. 2, 2008), 124. 
Kecerdasan yang dimiliki seseorang tidak mungkin dapat berkembang dengan baik tanpa dikembangkan atau di asah oleh orang lain. Seorang dikatakan cerdas bila ia dapat memecahkan masalah yang dihadapi dalam hidupnya dan mampu menghasilkan sesuatu yang berhargaatau berguna bagi umat manusia. ${ }^{8}$

Kecerdasan tidak dapat di ukur dari umum atau khusus sebab banyak factor yang mempengaruhi. Salah satu faktor yang menjadikan kecerdasan seseorang dapat berkembang dengan baik yaitu keluarga. Sejak anak terlahir pertama kalinya kedunia, kecerdasan yang ia pelajari adalah kecerdasan bahasa ibunya. Selama ini kita hanya terpaku pada pengertian bahwa orang yang cerdas pasti pintar sekolahnya, nilainya pasti baik. Kita mengukur kecerdasan hanya berdasarkan prestasi akademik. Atau kita bisa dengan mudah menggunakan hasil tes IQ untuk menentukan tingkat kecerdasan seseorang 9 . Pada dasarnya setiap anak memiliki berbagai kecerdasan dalam tingkatan dan indikator yang berbeda. Hal ini menunjukan bahwa semua anak pada hakikatnya adalah cerdas. Akan tetapi mereka mempunyai tingkat kecerdasan yang berbeda. Perbedaan tersebut menurut Musfiroh ditentukan oleh faktor rangsangan yang diberikan kepada anak pada saat anak masih berusia dini ${ }^{10}$.

Kecerdasan (inteligensi) merupakan sebuah kemampuan menyesuaikan diri dengan lingkungan atau belajar dari pengalaman. Manusia hidup bersosialisai dan berinteraksi di dalam lingkungannya yang kompleks ${ }^{11}$. Oleh karena itu ketika manusia dihadapkan dengan sebuah persoalan hidup manusia harus mampu menyesuaikan diri dengan lingkungan dan belajar dari pengalaman untuk menyelesaikan sebuah persoalan.

Kecerdasan intelektual tidak hanya mencakup aspek linguistik dan matematis saja, tetapi juga harus dilihat dari aspek kinetis, musical, visual-spatial, interpersonal, intrapersonal, dan naturalis. Jenis-jenis kecerdasan intelektual

${ }^{8}$ C. Asri Budiningsih, Belajar dan Pembelajaran (Jakarta: Rineka Cipta, 2012), 114.

${ }^{9}$ Adi W. Gunawan, Genius Learning Strategy: Petunjuk Praktis untuk Menerapkan Accelarated Learning (Jakarta: PT. Grame dia Pustaka Utama, 2004), 217.

${ }^{10}$ Takdiroatun Musfiroh, Pengembangan Kecerdasan Majemuk, (Tanggerang Selatan: Universitas terbuka, 2014), 13.

${ }^{11}$ Andrea T. Raharjo, Hubungan antara Multiple Intelligence dengan Prestasi Belajar Siswa kelas XI di SMA Negeri 10 Malang. (Jurnal Psikologi, Vol. 05 No. 1, 2010), 311-322. 
tersebut dikenal dengan Multiple Intelligence yang diperkenalkan oleh Howard Gardner pada tahun 1983. Gardner mengatakan bahwa kita cenderung lebih menghargai orang - orang yang ahli di dalam kemampuan logika (matematika) dan bahasa. Kita harus memberikan perhatian yang seimbang terhadap orangorang yang memiliki talenta (gift) di dalam kecerdasan yang lainnya seperti artis, arsitek, musikus, ahli alam, designer, penari, terapis, entrepreneurs, dan lain-lain. Sangat disayangkan bahwa saat ini banyak anak-anak yang memiliki talenta (gift), tidak mendapatkan reinforcement di sekolahnya. ${ }^{12}$

Kecerdasan majemuk (multiple intelligences) adalah sebuah penilaian yang dilihat secara deskriptif bagaimana individu menggunakan kecerdasannya untuk memecahkan masalah dan menghasilkan sesuatu. Pendekatan ini merupakan suatu alat yang dipergunakan untuk melihat pikiran manusia mengoperasikan lingkungannya, baik itu berhubungan dengan benda-benda yang konkret ataupun yang abstrak. Bagi Gardner tidak ada yang bodoh atau pintar yang ada anak yang menonjol dalam salah satu atau beberapa kecerdasan. ${ }^{13}$

Teori Multiple Intelligences didasarkan pada pemikiran bahwa kemampuan intelektual yang diukur melalui tes IQ sangatlah terbatas karena tes IQ hanya menekan pada kemampuan logika (matematika) dan bahasa. ${ }^{14}$

Apabila diperhatikan secara cermat teori tentang kecerdasan majemuk, sebenarnya merupakan fungsi dari dua belahan otak manusia, yakni otak kanan dan otak kiri. Otak kiri memiliki kemampuan dan potensi untuk memecahkan masalah problem matematik, logis dan fenomenal. Sedangkan otak kanan memiliki kemampuan untuk merespons hal-hal yang bersifat kualitatif, artistik dan abstrak, tetapi tetap harus diingat bahwa ini semua masih dalam kerangka kemampuan terhadap dunia luar, sedangkan pengetahuan tentang diri, belum dijangkau ${ }^{15}$.

\footnotetext{
${ }^{12} \mathrm{Ibid}, 311-322$.

${ }^{13}$ Khadijah, Media Pembelajaran Anak Usia Dini, (Medan: Perdana Publishing, 2015), 112.

${ }^{14}$ Andrea T. Raharjo, Hubungan antara Multiple intelligence dengan prestasi belajar siswa kelas XI di SMA Negeri 10 Malang. (Jurnal Psikologi, Vol. 05, No. 1, 2010), h. 311-322.

${ }^{15}$ Suharsono, Mencerdaskan Anak, Melejitkan Intelektual dan Spritual, Memperkaya Hasanah Batin, Kesalehan serta Kreativitas Anak IQ, EQ dan SQ, (Cet. I; Depok: Inisiasi Press, 2004), 47.
} 
Pembelajaran berbasis kecerdasan majemuk secara umum dapat diartikan sebagai proses pembelajaran yang memberi "ruang gerak" bagi setiap individu siswa untuk mengembangkan potensi kecerdasannya. Siswa dituntut agar dapat belajar secara enjoy, tidak merasa terpaksa, dan memiliki motivasi yang tinggi. Pada hakikatnya, pembelajaran berbasis kecerdasan majemuk dapat juga dimaknai sebagai pembelajaran yang membiarkan anak didik untuk selalu kreatif. Tentunya, kreativitas yang dibangun adalah bentuk kreatifan yang dapat mendukung terhadap keberlangsungan proses pembelajaran dengan menghasilkan target motivasi akademik yang membanggakan, jadi pengembangan kecerdasan majemuk adalah suatu cara atau tahapan kemampuan yang dimiliki oleh setiap anak dalam memecahkan suatu masalah dan menghasilkan sesuatu yang baru.

Howard Gardner mengembangkan konsep penilaian kecerdasan melalui kecerdasan majemuk dengan memandang manusia tidak hanya berdasarkan skor standar semata melainkan dengan ukuran kemampuan untuk menyelesaikan masalah yang terjadi dalam kehidupan manusia, kemampuan untuk menghasilkan persoalan baru untuk diselesaikan, kemampuan untuk menciptakan sesuatu atau memberikan penghargaan dalam budaya seseorang. ${ }^{16}$ Berdasarkan pengamatan dilingkungan masyarakat pada kenyataannya masih terdapat sebagian besar orang tua dan guru belum memahami akan potensi luar biasa yang dimiliki anak usia dini. Keterbatasan pengetahuan dan informasi yang dimiliki orang tua dan guru menyebabkan potensi yang dimiliki anak tidak berkembang optimal. ${ }^{17}$

Banyaknya faktor yang dapat mempengaruhi kecerdasan setiap anak membuat para pendidik sering kali ditemui berbagai kekecewaan dalam menghadapi berbagai macam anak, sehingga muncul rasa frustasi dalam menghadapi mereka. Hal ini wajar, rasa cemas akan ketidakberhasilan anak dalam melakukan suatu pelajaran atau pekerjaan akan berdampak terhadap harga diri anak tersebut. Pemahaman tentang kecerdasan individual masing-masing anak dan gaya belajar mereka akan membantu para pendidik dalam menghadapi anak

\footnotetext{
${ }^{16} \mathrm{H}$. Gardner, Multiple Intelligences: The Theory in Practice (New York: Basics Book, 2003), 235.

${ }_{17}$ Yuliani Nurani Sujiono dan Bambang Sujiono, Bermain Kreatif Berbasis Kecerdasan Jamak. (Jakarta: PT Indeks, 2010), 8.
} 
terutama dalam mengajari anak-anak dengan cara yang paling sesuai dengannya, atau dengan cara yang paling mudah untuk mereka dapat menguasai suatu pelajaran atau pekerjaan, menangkap informasi atau konsep atau berbagai keterampilan secara lebih cepat $^{18}$. Berdasarkan latar belakang yang telah diuraikan, maka untuk lebih memahami tentang kecerdasan majemuk yang dapat dikembangkan pada diri setiap anak didik perlu adanya pemahaman tentang teori multiple intelligences.

\section{METODE}

Penelitian ini adalah penelitian kualitatif yang bersifat studi pustaka (library research), yakni penelitian yang dilakukan dengan mengumpulkan data melalui buku, artikel yang dipublikasikan dalam jurnal dan literatur yang tersedia. Kajian pustaka ini untuk membangun konsep dan menjadi dasar studi penelitian. Penelitian ini menggunakan kualitatif yang menghasilkan informasi berupa data deskriptif yang terdapat dalam teks yang diteliti. proses analisis ini dilakukan bersama dengan proses pengumpulan data. Terdapat empat tahapan dalam analisis ini yakni : Pengumpulan data, Reduksi data, Penyajian data dan Penarikan kesimpulan.

Dua bentuk kecerdasan yang akan dibahas dalam penelitian ini adalah Kecerdasan Linguistik (Linguistic intelligence) dan Kecerdasan Interpersonal (Interpersonal Intelligence) pada anak usia dini.

\section{HASIL DAN PEMBAHASAN}

\section{Hakikat Anak Usia Dini}

Setiap orang ingin mempunyai anak yang cerdas karena kecerdasan adalah modal penting bagi si anak untuk mengarungi kehidupan. Generasi yang sehat dan cerdas diharapkan dapat menjadi tonggak kemajuan bangsa. Hal ini pula yang menjadi tanggungjawab orangtua sebagai orang yang paling dekat dengan anak. ${ }^{19}$

18 Yuliani Nurani Sujiono, Konsep Dasar Pendidikan Anak Usia Dini Dini. (Jakarta: Indeks, 2012), 179-183.

${ }^{19}$ Sri Widayati, dan Utami Widijati, Mengoptimalkan 9 Zona Kecerdasan Majemuk Anak (Yogyakarta: LUNA PUBLISHER, 2008), 1. 
Sebagai orangtua masa kini, kita seringkali menekankan agar anak kita menjadi orang yang berprestasi dalam semua bidang. Misalnya, kita ingin mereka menjadi juara dengan harapan ketika dewasa mereka bisa memasuki perguruan tinggi yang bergengsi. Kita sebagai bagian dari masyarakat memiliki kepercayaan bahwa sukses di sekolah adalah kunci untuk kesuksesan hidup di masa depan. Namun dalam kenyatannya kita tidak bisa mengingkari bahwa sangat sedikit orang-orang yang sukses di dunia ini yang menjadi juara di masa sekolah. Untuk mendorong perkembangan kecerdasan anak secara optimal, maka orangtua berperan penting dalam memberikan stimulasi. ${ }^{20}$

Setiap anak terlahir dengan memiliki lebih dari satu kecerdasan yang dimilikinya dan semua itu perlu dikembangkan agar dapat tumbuh dengan baik. Kecerdasan yang dimiliki seseorang tidak mungkin dapat berkembang dengan baik tanpa dikembangkan atau di asah oleh orang lain. Seorang dikatakan cerdas bila ia dapat memecahkan masalah yang dihadapi dalam hidupnya dan mampu menghasilkan sesuatu yang berharga/berguna bagi umat manusia. ${ }^{21}$

Usia dini merupakan periode awal yang paling penting dan mendasar di sepanjang rentang pertumbuhan dan perkembangan kehidupan manusia. Salah satu periode yang menjadi penciri masa usia dini adalah the golden ages atau periode keemasan. Banyak konsep dan fakta yang ditemukan memberikan potensi keemasan pada masa usia dini, dimana semua potensi anak berkembang pesat. Masa anak usia dini adalah masa eksplorasi, masa identifikasi/imitasi, masa peka, masa bermain. ${ }^{22}$

Pertumbuhan dan perkembangan anak memiliki perbedaan satu sama lain. Penelitian tentang otak menunjukkan bahwa apabila anak diberikan rangsangan sejak usia dini, maka akan ditemukan anak-anak yang mempunyai potensi unggul di dalam dirinya karena pada dasarnya setiap anak mempunyai kemampuan tak terbatas di dalam dirinya. Maka itu anak memerlukan program pendidikan yang mampu membuka dan merangsang kapasitas belajar dan pengembangan potensi

\footnotetext{
${ }^{20}$ Ibid, 23-24.

${ }^{21}$ C. Asri Budiningsih, Belajar dan Pembelajaran (Jakarta: Rineka Cipta, 2012), 114.

${ }^{22}$ Trianto, Desain Pengembangan Pembelajaran Tematik Bagi Anak Usia Dini TK/RA \& Anak Kelas Awal SD/MI, (Jakarta: Kencana, 2011), 6-7.
} 
diri anak melalui pembelajaran sedini mungkin. Potensi diri yang telah dimiliki oleh anak harus dikembangkan sedini mungkin karena apabila potensi itu tidak dapat direalisasikan dan dikembangkan, maka sama artinya anak tersebut telah kehilangan periode emas dalam hidupnya. ${ }^{23}$

UU No. 23 Tahun 2002 tentang Perlindungan Anak pasal 4 menyebutkan bahwa anak mempunyai hak untuk tumbuh dan berkembang, bermain, beristirahat, berekreasi dan belajar dalam suatu pendidikan. Termasuk pendidikan dengan model pembelajaran yang mengarah pada optimalisasi potensi sesuai dengan daya cipta anak untuk pertumbuhan dan perkembangan melalui bermain, sehingga suasana belajar terasa lebih menyenangkan dan tidak merasa dipenjara. ${ }^{24}$

\section{Pengertian Kecerdasan}

Pengertian kecerdasan dalam pandangan lama menurut Steven J. Gould dari Harvard adalah kapasitas mental umum yang meliputi kemampuan untuk memberikan alasan, membuat rencana, memecahkan masalah, berpikir abstrak, menghadapi ide yang kompleks, belajar dari pengalaman, dan dapat diukur dengan tes IQ yang tidak dipengaruhi oleh budaya dan genetik yang berperan besar. Secara bertahap IQ distabilkan selama masa anak, dan setelah masa itu hanya sedikit perubahannya. Definisi yang mudah dimengerti adalah kemampuan untuk mengerti ide yang kompleks, mampu beradaptasi dengan efektif terhadap lingkungannya, mampu belajar dari pengalaman, mampu melaksanakan tugas dalam berbagai macam situasi, mampu mengatasi hambatan dengan menggunakan pikirannya. $^{25}$

Howard Gardner menyatakan bahwa kecerdasan adalah kemampuan untuk menyelesaikan masalah, atau menciptakan produk yang berharga dalam satu atau beberapa lingkungan budaya dan masyarakat ${ }^{26}$. Menurut Gardner kecerdasan

\footnotetext{
${ }^{23}$ Sumiyati, Konsep Dasar Pendidikan Anak Usia Dini dalam Islam, (Yogyakarta: Cakrawala Institute, 2014), 12-13.

${ }^{24}$ Lara Fridani, 2009. Inspiring Education Pendidikan Anak Usia Dini, (Jakarta: PT. Elex Media Komputindo), 8.

${ }^{25} \mathrm{H}$. Gardner, Multiple Intelligences: The theory in practice. (New York: Basics Book, 2003), 235-236.

${ }^{26}$ Ibid, 22.
} 
bukanlah kemampuan yang sudah ada sejak lahir dan akan tetapi sepanjang hidup yang tidak dapat dikembangkan. Kecerdasan selalu dapat dikembangkan lewat pembelajar dan seorang guru mempunyai peran untuk membantu perkembangan kecerdasan anak. Arti kecerdasan yang selama ini diyakini para orang tua hanyalah kecerdasan intelektual saja. Padahal, seseorang dikatakan cerdas apabila ia mampu mengakomodasi empat aspek lainya yaitu, kecerdasan intelektual, emosional, moral, dan spiritual. Konkritnya, seseorang dikatan cerdas apabila ia mampu berelasi dengan orang lain, mampu mengendalikan susasana hati, dan mampu melihat dirinya sedang dalam kondisi yang bagaimana. Apakah ia mampu melibatkan unsur intelektualnya, kognisinya, afeksinya, ataukah unsur-unsur lainnya. $^{27}$

Pendapat tersebut didukung oleh Prasetyo \& Andrian yang mengatakan bahwa kecerdasan majemukmerupakan gambaran sifat alamiah manusia dari sebuah perspektif kognitif, seperti bagaimana seseorang merasakan dan menyadari suatu keadaan, terutama mengelola informasi baru yang masuk keedalam diri sendiri sesorang dan menggunakan kepastiannya untuk kehidupan sehari-hari. $^{28}$

Wechsler menjelaskan bahwa, intelegensi adalah suatu kemampuan secara global dalam individu untuk bersikap secara tepat, berpikir secara rasional, dan dapat menghadapi lingkungan secara efektif. Pandangan lain dari ahli lainnya mendefinisikan intelegensi sebagai kemampuan seseorang menyesuaikan diri mempertimbangkan, mengerti, dan berpikir dengan baik. Selain itu, intelligensi juga dianggap sebagai kemampuan menangani masalah yang memiliki ciri-ciri: (1) mengandung kesulitan, (2) kompleks, (3) abstrak, (4) ekonomis, (5) mengarah pada satu tujuan, dan (6) mempunyai nilai social. ${ }^{29}$

Kecerdasan manusia seharusnya dilihat dari tiga komponen utama; Pertama, kemampuan untuk mengarahkan pikiran dan tindakan (the ability to direct thought and action). Kedua, kemampuan untuk mengubah arah pikiran atau tindakan (the

\footnotetext{
${ }^{27}$ Ibid, 95 .

${ }^{28}$ Prasetyo, Reza dan Yeni Andriani, Multiply Your Multiple Intelligences: Melatih 8 Kecerdasan Majemuk pada Anak dan Dewasa, (Yogyakarta: Andi Offset, 2009), 91.

${ }^{29}$ Ahmad Afiif, Psikologi Guru, (Makassar: Alauddin University Press, 2014), 93.
} 
ability to change the direction of thought and action). Ketiga, kemampuan untuk mengkritisi pikiran dan tindakan sendiri (ability to critisize own thoughts and actions). Kemampuan manusia tidak bisa dikaji dengan membuat suatu pengelompokan berdasarkan kecenderungan, perubahan, dan mengoreksi pikiran dan tindakan, tetapi harus dilihat dari kemampuan untuk beraktivitas dengan menggunakan gagasan-gagasan dan simbolsimbol secara efektif (kemampuan abstrak), dan kemampuan untuk menyesuaikan diri dengan lingkungan baru (kemampuan sosial). ${ }^{30}$

Menurut Gadner kecerdasan manusia tidak bersifat tunggal, artinya kecerdasan manusia tidak bisa hanya diukur dari kecerdasan dalam menjawab materimateri dalam pembelajarn semata, namunkecerdasan manusia itu juga dinilai berdasarkan: (a) kemampuan untuk menyelesaikan masalah yang terjadi dalam kehidupan. (b) kemampuan menemukan persoalan-persoalan baru untuk diselesaikan atau dicari solusinya. (c) kemampuan untuk menciptakan sesuatu dan memberikan penghargaan dalam budaya seseorang.

\section{Bentuk-bentuk Multiple Intelegence}

Teori kecerdasan (Multiple Inteligence) atau ada yang menyebutnya sebagai teori "kecerdasan ganda" yang terkenal belakangan ini, untuk pertama kali dikemukakan oleh Howard Gadner dari Harvard Graduate School of Education and Psychology di Harvard University Amerika Serikat. Dalam bukunya Frames of Mind (1983), Gadner menyatakan bahwa pada dasarnya manusia mempunyai tujuh jenis kecerdasan, yaitu kecerdasan bahasa, matematis logis, spasial, kinestetis jasmani, musikal, interpersonal dan kecerdasan intrapersonal. Kemudian pada tahun 2000, Gadner dalam bukunya, Intelligence Reframed, menambahkan 2 lagi jenis kecerdasan yaitu kecerdasan naturalis dan kecerdasan eksistensialis. ${ }^{31}$

\footnotetext{
${ }^{30}$ Yaumi, Muhammad dan Nurdin Ibrahim, Pembelajaran Berbasis Kecerdasan Jamak (Multiple Intelligences) Mengidentifikasi dan Mengembangkan Multitalenta Anak. (Jakarta: Prenadamedia Group, 2016), 10-11.

${ }^{31}$ Dalton, Creative Thinking and Cooperative Talk in Small Group, (Australia: Thomas Nelson, 1990), 89.
} 
Multiple inteligences (kecerdasan jamak) merupakan kemampuan seseorang dalam berpikir, memecahkan masalah, bertindak dan berperilaku sesuai dengan apa yang dihadapi, dan dengan berbagai keterampilan dan bakat yang dimiliki, seseorang dapat menyelesaikan berbagai persoalan dalam kehidupan sehari-hari. ${ }^{32}$

Teori Multilple Intelegence adalah validasi tertinggi gagasan bahwa perbedaan individu adalah penting. Pemakaiannya dalam pendidikan sangat tergantung pada pengenalan, pengakuan dan penghargaan terhadap setiap atau berbagai cara siswa belajar, di samping pengenalan, pengakuan dan penghargaan terhadap setiap minat masing-masing siswa. Teori kecerdasan majemuk bukan hanya mengakui perbedaan individual ini untuk tujuan-tujuan praktis, seperti pengajaran dan penilaian, tetapi juga menganggap serta menerimanya sebagai sesuatu yang normal, wajar, bahkan menarik dan sangat berharga. ${ }^{33}$

Gardner dalam bukunya Jasmine mengenalkan teori kecerdasan majemuk yang menyatakan bahwa kecerdasan meliputi delapan kecerdasan. Yaitu linguistik, matematis, visual, musikal, kinestetik, interpersonal, intrapersonal, dan naturalis. Teori tersebut didasarkan pada pemikiran bahwa kemampuan intelektual yang diukur melalui tes $I Q$ sangatlah terbatas, karena tes $I Q$ hanya menekan pada kemampuan logika (matematika) dan bahasa. Padahal setiap orang mempunyai cara yang unik untuk menyelesaikan persoalan yang dihadapinya. Kecerdasan bukan hanya dilihat dari nilai yang diperoleh seseorang. Kecerdasan merupakan kemampuan yang dimiliki oleh seseorang untuk melihat suatu masalah, lalu menyelesaikan masalah tersebut atau membuat sesuatu yang dapat berguna bagi orang lain. ${ }^{34}$

a. Kecerdasan linguistik

Kecerdasan verbal-linguistik mengacu pada kepekaan individu terhadap suara, irama, danmakna kata-kata, serta kepekaan terhadap berbagai fungsi

${ }^{32} \mathrm{H}$. Gardner, Multiple Intelligences: The theory in practice. (New York: Basics Book, 2003), 235-236.

${ }^{33}$ Julia Jasmine, Panduan Praktis Mengajar Berbasis Kecerdasan Majemuk (Cet. I; Bandung: Nuansa, 2007), 13.

${ }^{34}$ Ibid, 14. 
bahasa. ${ }^{35}$ Kecerdasan linguistik merupakan kecakapan berpikir melalui kata-kata, menggukan bahasa untuk menyatakan dan memaknai arti yang kompleks. Para penulis, ahli bahasa, sastrawan, jurnalis, orator, wartawan adalah orang-orang yang memiliki kecerdasan linguistic. ${ }^{36}$

b. Kecerdasan logis-matematis

Adalah kemampuan untu menghitung, mengukur, mempertimbangkan proposisi dan hipotesis, dan melaksanakan operasi matematika.Kecerdasan ini meliputi kepekaan pada pola dan hubungan logis, pernyataan dan dalil (jika-maka, sebab-akibat), fungsi logis dan abstraksi-abstraksi lain. ${ }^{37}$

c. Kecerdasan visual-spasial

Adalah kepekaan terhadap warna, garis, bentuk, ruang, dan hubungan antara unsur tersebut, kemampuan membayangkan, mempresentasikan ide secara visualspasial, dan mengorientasikan diri secara tepat dalam matriks spasial. ${ }^{38}$. Kecerdasan visual-spasial memungkinkan orang membayangkan bentuk geometri atau tiga dimensi dengan lebih mudah karena ia mampu mengamati dunia spasial secara akurat dan mentransformasikan persepsi ini termasuk di dalamnya adalah kapasitas untuk memvisualisasi, menghadirkan visual dengan grafik atau ide spasial, dan untuk mengarahkan diri sendiri dalam ruang secara tepat. Kecerdasan ini juga membuat individu mampu menghadirkan dunia ruang secara internal dalam fikirannya. Cara inilah yang digunakan pelaut atau pilot pesawat terbang ketika mengarungi ruang dunia. Begitu pula bagi seorang pemain catur yang menghadirkan sebuah dunia spasial yang terbatas. ${ }^{39}$

d. Kecerdasan Gerak Tubuh

Menurut Laurel Schmidt dikutip Amstrong17 setiap orang memiliki kemampuan gerak tubuh dan beberapa orang berpendapat bahwa kemampuan

${ }^{35}$ Fred Lunenburg, Applying Multiple Intelligences in The Classroom: AFresh Look at Teaching Writing. (International Journal of Scholary Academic Intellectual Diversity, Vol. 16, No. 1, 2014), 2.

${ }^{36}$ Nana Sukmadinata Syaodih, Landasan Psikologi Proses Pendidikan. (Bandung: PT Remaja Rosdakarya, 2011), 96.

${ }^{37}$ Ahmad Afiif, Psikologi Guru. (Makassar: Alauddin University Press, 2014), 99.

${ }^{38}$ Bayuni. Pengembangan LKS Berbasis Kecerdasan Ganda Subtema Tugasku Sehari-Hari di Rumah. (Jurnal Ilmu Pendidikan. Vol. 3, hlm. No.2, 2016), 2-26.

${ }^{39}$ Kadek Suarca, Soetjiningsih dan Iga Endah Ardjana. Kecerdasan Majemuk pada Anak.. (Jurnal Sari Pediatri, Vol. 07, No. 2, 2005), 85-92. 
mengontrol fisik bukanlah suatu bentuk dari kecerdasan. Namun Gardner dan peneliti lain dalam bidang kecerdasan majemuk mempertahankan pendapatnya. Individu dengan kecerdasan gerakan tubuh secara alamiah memiliki tubuh yang atletis, memiliki ketrampilan fisik, kemampuan dan merasakan bagaimana seharusnya tubuh membentuknya sehingga mahir menggunakan seluruh tubuh untuk mengekspresikan ide dan perasaan. Kecerdasan ini juga termasuk ketrampilan koordinasi, keseimbangan, kelenturan, kekuatan, fleksibilitas dan kecepatan. $^{40}$

Ketrampilan yang dapat dilihat pada anak dengan kecerdasan gerak tubuh antara lain berprestasi dalam bidang olah raga kompetitif, bergerak-gerak ketika sedang duduk, terlibat dalam kegiatan fisik seperti berenang, bersepeda, mendaki dan lain-lain. Mereka perlu menyentuh sesuatu yang ingin dipelajari, menikmati melompat, lari, gulat atau yang serupa lainnya. Anak dengan kecerdasan gerak tubuh juga memperlihatkan ketrampilan dalam bidang kerajinan tangan, pandai menirukan gerakan, kebiasaan, atau perilaku orang lain, sering "merasakan" jawaban masalah yang dihadapi di rumah atau di sekolah, menikmati bekerja dengan tanah liat, melukis dengan jari atau kegiatan kotor lainnya, sangat suka membongkar berbagai benda dan kemudian menyusunnya lagi. ${ }^{41}$

e. Kecerdasan interpersonal

Merupakan kemampuan mengorganisasikan orang lain dan mengomunikasikan secara jelas apa yang perlu dilakukan, berempati kepada orang lain, membedakan dan menginterpretasikan berbagai jenis komunikasi dengan orang lain.Berbeda dengan kecerdasan interpersonal, kecerdasan intrapersonal merupakan kecakapan dalam memahami kehidupan emosional, membedakan emosi orang-orang, pengetahuan tentang kekutan dan kelemahan $\operatorname{diri}^{42}$

${ }^{40}$ Thomas Amstrong, In Their Own Way: Discovering And Encouraging Your Child's Multiple Intelligences, (Jakarta: PT Gramedia Pustaka Utama, 2003), 16.

${ }^{41}$ Ibid. h. 53 2004), 4 .

${ }^{42}$ Thomas Amstrong, Menerapkan Multiple Intelligences di Sekolah, (Bandung: Kaifa, 
Pada dasarnya, anak-anak akan belajar menyesuaikan diri dengan tuntutan sosial dan menjadi pribadi yang mampu berinteraksi dengan lingkungan sosialnya, hal ini bergantung pada empat faktor. Pertama, faktor kesempatan bersosialisasi. Kedua, mampu menampilkan topik yang dapat dipahami dan menarik bagi orang lain tapi pembicaraan yang bersifat sosial, tidak bersifat egosentrik dan dapat diterima oleh lingkungan sosialnya. Ketiga, anak harus mampunyai motivasi, bergantung pada tingkat kepuasan yang diperoleh dari aktivitas sosial anak. Jika ia memperoleh kesenangan melalui hubungan sosial dengan orang maka iapun akan mengulangi perilaku tersebut. Keempat, metode belajar saat berinteraksi sosial dengan orang lain yang efektif, adalah melalui teladan yang diberi oleh orang tua ataupun pendidik di rumah dan di sekolah. ${ }^{43}$

f. Kecerdasan musikal

Adalah kapasitas berpikir dalam musik untuk mampu mendengarkan polapola dan mengenal serta mungkin memanipulasinya. Kecerdasan jasmaniahkinestetik adalah kemampuan-kemampuan fisik yang spesifik seperti koordinasi, keseimbangan, keterampil, kekuatan, kelenturan, dan kecepatan ataupun kemampuan untuk menggunakan seluruh tubuh dalam mengekspresikan ide, perasaan, dan menggunakan tangan untuk menghasilkan atau mentransformasi sesuatu. $^{44}$

Anak dengan kecerdasan musikal mudah mengenali dan mengingat nadanada. Ia juga dapat mentransformasi kata-kata menjadi lagu dan menciptakan berbagai permainan musik. Merekapun pintar melantunkan bait lagu dengan baik dan benar, menggunakan kosa kata musikal, dan peka terhadap ritme, ketukan, melodi atau warna suara dalam sebuah potongan komposisi musik. ${ }^{45}$

g. Kecerdasan intrapersonal

Merupakan kemampuan seseorang untuk memahami diri sendiri, mengetahui siapa dirinya, apa yang dapat dilakukan, apa yang ingin ia lakukan,

\footnotetext{
${ }^{43}$ Kadek Suarca, Soetjiningsih dan Iga Endah Ardjana. Kecerdasan Majemuk pada Anak, (Jurnal Sari Pediatri, Vol. 07, No. 2, 2005), 85-92.

${ }^{44}$ Wardhani, Galuh dkk. Metode Pembelajaran Fisika Berdasarkan Teori Multiple Intelligences pada Materi Perpindahan Kalor. (Jurnal Radiasi, vol. 6, No. 1, 2015), 42.

${ }^{45}$ Kadek Suarca, Soetjiningsih dan Iga Endah Ardjana. Kecerdasan Majemuk pada Anak, (Jurnal Sari Pediatri, Vol. 07, No. 2, 2005), 85-92.
} 
bagaimana reaksi diri terhadap suatu situasi dan memahami situasi seperti apa yang sebaiknya ia hindari serta mengarahkan dan mengintrospeksi diri. ${ }^{46}$

h. Kecerdasan naturalis

Adalah kemampuan dalam melakukan kategorisasi dan membuat hierarrki terhadap keadaan organisme seperti tmbuh-tumbuhan, binatang, dan alam. ${ }^{47}$ Individu yang kuat dalam kecerdasan ini akan sangat optimal belajarnya bila menggunakan alat peraga yang menghadirkan fenomena alam ke dalam kelas. Adanya kegiatan seperti studi wisata akan sangat mendukung kemampuan belajar mereka.

Menurut Amstrong, kecerdasan spiritual diyakini sebagai kecerdasan yang paling esensial dalam kehidupan manusia dibandingkan dengan berbagai jenis kecerdasan lain seperti kecerdasan intelektual, emosional, dan kecerdasan sosial. ${ }^{48}$ 4. Pengembangan Kecerdasan Linguistik dan Kecerdasan Interpersonal

Menurut Wiryokusumo pengembangan adalah upaya pendidikan baik formal maupun nonformal yang dilaksanakan secara sadar, berencana, terarah, teratur, dan bertanggungjawab dalam rangka memperkenalkan, menumbuhkan, membimbing dan mengembangkan suatu dasar kepribadian yang seimbang, utuh, serta selaras untuk menambahkan, meningkatkan dan mengembangkan diri ke arah ketercapaiannya martabat, mutu, dan kempuan manusiawi yang optimal serta pribadi mandiri. $^{49}$

Sembilan jenis kecerdasan dalam konsep multiple intelligences sedapat mungkin secara maksimal diterapkan dengan prinsip-prinsip yang telah dikembangkan oleh beberapa ahli psikologi perkembangan. Prinsip-psinsip kecerdasan majemuk dapat diterapkan dengan berbagai metode pengajaran yang

${ }^{46}$ Howard Gardner, Multiple Intelligences: The Theory in Practice (New York: Basics Book, 2003), 66.

${ }^{47}$ Yaumi, Muhammad dan Nurdin Ibrahim, Pembelajaran Berbasis Kecerdasan Jamak (Multiple Intelligences) Mengidentifikasi dan Mengembangkan Multitalenta Anak. (Jakarta: Prenadamedia Group, 2016), 21.

${ }^{48}$ Thomas Amstrong, Menerapkan Multiple Intelligences di Sekolah, (Bandung: Penerbit Kaifa, 2004), 4.

${ }^{49}$ Iskandar Wiryokusumo, Dasar-Dasar Pengembangan Kurikulum, (Jakarta: Bumi Aksara, 2011), 4 . 
ada, dan memperhatikan dengan seksama terhadap minat dan bakat peserta didik. $^{50}$

Haggerty dalam bukunya Paul Suparno mengungkapkan beberapa prinsip umum untuk membantu mengembangkan kecerdasan majemuk pada siswa, yaitu: 1) Pendidikan harus memperhatikan semua kemampuan intelektual. Maka, mengajar tidak hanya terfokus pada kemampuan dari intelligence yang lain. Kemampuan yang hanya logika dan bahasa tidak cukup untuk menjawab persoalan manusia secara menyeluruh. Perlu dikenalkan pula intelligence yang lain. 2) Pendidikan seharusnya individual, pendidikan harusnya lebih personal, dengan memperhatikan intelligence setiap siswa, mengajar dengan cara, materi dan waktu yang sama, jelas tidak menguntungkan bagi siswa yang berbeda intelligence-nya, jadi, guru perlu banyak cara untuk membantu siswa. 3) Pendidikan harus menyemangati siswa untuk dapat menentukan tujuan dan program belajar mereka. Siswa perlu diberi kebebasan untuk menggunakan cara belajar dan cara kerja sesuai dengan minat mereka. 4) Sekolah harus menyediakan sarana dan fasilitas yang dapat dipergunakan siswa untuk melatih kemampuan intelektual mereka berdasarkan intelligence majemuk. 5) Evaluasi belajar harus lebih konstektual dan bukan tes tertulis saja. Evaluasi lebih harus berupa pengalaman lapangan langsung dan dapat diamati bagaimana performa siswa, apakah langsung maju atau tidak. 6) Pendidikan sebaiknya tidak dibatasi di dalam gedung sekolah, intelligence majemuk memungkinkan juga dilaksanakan di luar sekolah, lewat masyarakat, kegiatan ekstra, serta kontak dengan orang luar dan para ahli. ${ }^{51}$

Kecerdasan linguistik atau kecerdasan bahasa. Orang yang memiliki kecerdasan ini pandai mengolah kata-kata. Sebagian di erantara meka pandai berkata-kata (misalnya: presenter, rohaniwan, pendongeng, mc, dsb). Sebagian lagi pandai menulis (misalnya: novelis, penulis buku, dsb). Ciri-cirinya Suka membaca, gemar menulis (puisi, cerpen, novel, diary, dsb), suka bermain scrable

\footnotetext{
${ }^{50}$ Howard Gadner, “A Reply to Perry D. Klein's. Multiplying the Problems of Intelligence by Eight", (Canadian Journal of Education, 1999).

${ }^{51}$ Paul Suparno, Teori Intelligence Ganda dan Aplikasinya di Sekolah, Cara Menerapkan Teori Multiple Intelligencess Howard Gardner (Cet. II; Yogyakarta: Kanisius, 2004), 65.
} 
atau mengisi TTS, pandai bercerita, suka memelesetkan atau memarodikan katakata, lebih suka mendengar secara lisan (auditory), mudah mengingat kata-kata aneh, suka menghibur orang lain atau diri sendiri dengan serangkaian kata/kalimat, suka berintonasi dalam berkata-kata, punya banyak perbendaharaan kata, mudah menemukan kejanggalan bahasa dalam tulisan atau kata-kata orang lain, suka menghabiskan waktu di toko buku. ${ }^{52}$

Cara utama untuk mengembangkan kecerdasan linguistic ini adalah dengan membaca berbagai buku, majalah, dan litaratur lainnya. Ada baiknya membiasakan diri menulis sesuatu (pengalaman hidup sehari-hari, atau apa pun yang didapat ketika membaca sesuatu, menonton film, atau bersaat teduh). ${ }^{53}$

Anak dengan kecerdasan bahasa yang menonjol biasanya senang membaca, pandai bercerita, senang menulis cerita atau puisi, senang belajar bahasa asing, mempunyai perbendaharaan kata yang baik, pandai mengeja, senang membicarakan ide-ide dengan teman-temannya, memiliki kemampuan kuat dalam mengingat nama atau fakta, menikmati permainan kata (utak-utik kata, plesetan atau pantun, teka-teki silang, atau bolak-balik kata) dan senang membaca tentang ide-ide yang menarik minatnya. Kecerdasan dalam bidang ini menuntut kemampuan anak untuk menyimpan berbagai informasi yang berkaitan dengan proses berfikirnya. ${ }^{54}$ Anak yang memiliki kecerdasan interpersonal yang tinggi biasanya mampu dengan baik bekerja dalam kelompok dan sering berperan sebagai pemimpin. ${ }^{55}$

\section{PEMBAHASAN}

\section{Prinsip Pengembangan kecerdasan Linguistic pada anak usia dini}

kecerdasan linguistik adalah kemampuan menggunakan kata-kata secara efektif, baik memengaruhi maupun memanipulasi. Dalam kehidupan sehari-hari

${ }^{52}$ Nurul H. Rofiah, Menerapkan Multiple Intellegences dalam Pembelajaran di Sekolah Dasar, (Jurnal Dinamika Pendidikan Dasar. Vol. 08. No. 1, 2016), 68-79.

${ }^{53}$ Ibid, 68-79.

${ }^{54}$ Thomas Amstrong, Setiap Anak Cerdas: Panduan Membantu Anak Belajar dengan Memanfaatkan Multiple Intelligence-nya, terj. Rina Buntaran, (Jakarta: Gramedia Pustaka Utama, 2002), 12.

${ }^{55}$ Munif Chatib dan Alamsyah Said, Sekolah Anak-Anak Juara: Berbasis Kecerdasan Jamak dan Pendidikan Berkeadilan, (Bandung: Kaifa, 2012), 95. 
kecerdasan linguistik bermanfaat untuk berbicara, mendengarkan, membaca dan menulis. ${ }^{56}$ Dari pengertian di atas dapat diketahui dahwa pengembangn kecerdasan linguistik yaitu suatu proses yang menjadikan bertambah dan berubah dalam hal pengetahuan bahasa baik secara lisan maupun tulisan. Pada kecerdasan linguistik yang dimiliki anak seperti dapat berbicara, membaca dan menulis sesuai dengan perkembangan usianya.

Peserta didik dengan kecerdasan bahasa yang tinggi umumnya ditandai dengan kesenangannya pada kegiatan yang berkaitan dengan penggunaan suatu bahasa seperti membaca, menulis karangan, membuat puisi, membuat kata-kata mutiara, dan sebagainya. Peserta didik seperti ini juga cenderung memiliki daya ingat yang kuat, misalnya terhadap nama-nama orang, istilah-istilah baru, maupun halhal yang sifatnya detail. Mereka cenderung lebih mudah belajar dengan cara mendengarkan dan verbalisasi. Dalam hal penguasaan suatu bahasa baru, peserta didik ini umumnya memiliki kemampuan yan lebih tinggi dibandinkan dengan peserta didik lainnya. ${ }^{57}$ Mereka gemar membaca, menulis, dan berbicara, dan suka bercengkerema dengan kata-kata. Mereka mengkhidmati kata-kata bukan hanya untuk makna tersurat dan tersiratnya semata namun juga bentuk dan bunyinya, serta untuk citra yang tercipta ketika kata-kata dirancang dalam cara lain dan berbeda dari yang biasa. ${ }^{58}$

Secara teoritis berdasarkan aspek perkembangannya, seorang anak dapat belajar dengan sebaik-baiknya apabila fisiknya dipenuhi dan mereka merasa aman dan nyaman secara psikologis. Selain itu, hal lain yang perlu diperhatikan adalah bahwa anak membangun pengetahuannya sendiri, anak belajar melalui interaksi social dengan orang dewasa dan anak-anak lainnya, anak belajar melalui bermain, minat anak dan rasa keingintahuannya memotivasinya

\footnotetext{
${ }^{56}$ Igrea Siswanto dan Sri Lestari, Panduan Bagi Guru dan Orangtua Pembelajaran Atraktif dan 100 Permainan Kreatif untuk PAUD, (Yogyakarta: Andi, 2012), 122.

${ }^{57}$ Hamzah B. Uno dan Masri Kuadrat Umar, Mengelola Kecerdasan dalam Pembelajaran; Sebuah Konsep Pembelajran Berbasis Kecerdasan, (Jakarta: Bumi Aksara, 2009), 12.

${ }^{58}$ Julia Jasmine, Metode Mengajar Mutiple Intellegences, (Bandung: Nuansa, 2016), 17.
} 
untuk belajar sambil bermain, serta terdapat variasi individual dalama perkembangan dan belajar. ${ }^{59}$

Kecerdasan lingustik muncul dari berbagai bentuk dan aktivitas berikut: ${ }^{60}$

a. Anak senang berkomunikasi dengan orang lain, baik dengan teman sebaya maupun orang dewasa usia 2-6 tahun.

b. Anak senang bercerita panjang lebar tentang pengalaman sehari - hari, apa yang dilihat dan diketahui (usia 3-6 tahun).

c. Anak mudah mengingat nama teman dan keluarga (usia 2-6 tahun), tempat atau hal - hal sepele yang pernah didengar atau diketahui termasuk jingle ikan (usia 3-6 tahun).

d. Anak suka membawa buku dan pura-pura membaca (2-4 tahun), suka buku dan cepat mengeja melebihi anak-anak seusianya 9 usia 4-6 tahun.

e. Anak mudah mengucapkan kata-kata, menyukai permainan kata, suka melucu (usia 3-6 tahun).

f. Anak memiliki lebih banyak kosa kata daripada anak-anak seusianya yang ditunjukan saat anak berbicara.

g. Anak suka dan memperhatikan cerita atau pembacaan cerita dari pendidik (usia 2-6 tahun) dan dapat menceritakan kembali dengan baik (usia 4-6 tahun).

h. Anak suka meniru tulisan disekitarnya dan menunjukan pencapaian diatas anak-anak sebayanya; mampu membuat pengulangan linear, huruf acak, dan menulis dengan ejaan bunyi atau fonetik dan menulis dengan ejaan sebagian sudah benar.

i. Anak suka membaca tulisan pada label makanan elektronik, papan nama tokorumah makan, judul buku, dan sejenisnya.

j. Anak menikmati permainan linguistik, seperti tebak-tebakan, acak huruf, dan mengisi kata pada potongan cerita.

\footnotetext{
${ }^{59}$ Yuliani Nurani S, dkk. Bermain Kreatif Berbasis Kecerdasan Jamak, ( Jakarta: PT. Indeks, 2010), 20-21.

${ }^{60}$ Takdirotun Musfiroh, Pengembangan Kecerdasan Majemuk, (Jakarta: Universitas Terbuka, 2010), 27-28.
} 


\section{Metode Pengembangan Kecerdasan Linguistik}

Kecerdasan linguistik pada anak usia dini dapat dikembangkan dengan berbagai cara diantaranya: ${ }^{61}$

a. Mengajak anak berbicara, sejak bayi anak memiliki indera pendengaran yang cukup baik sehingga baik sekali berkomunikasi dan menstimulasi anak mengajak bicara dengan terus menerus mengajak anak berbicara merupakan langkah awal melatih berbicara yang merupakan unsur penting dalam berkomunikasi dan ketrampilan sosial.

b. Membacakan cerita Membacakan cerita atau mendongeng dapat dilakukan kapan saja, membimbing anak untuk membacakan cerita dengan isi berulang ulang sebagai bekal penanaman kelak dan membantu meningkatka konsentrasi anak.

c. Bermain huruf Mengenalkan huruf-huruf abjad dapat dilakukan sejak dini, anak belajar mengenal huruf dengan melihat dan menyentuhnya.

d. Merangkai cerita Sebelum dapat membaca anak-anak pada umumnya gemar membaca gambar, berikan anak potongan-potongan gambar dan biarkan anak mengungkapkan apa yang ia pikirkan tentang gambar itu.

e. Berdiskusi atau bercakap-cakap Mungkin hal yang sulit untuk berdiskusi dengan anak kecil, sebenarnya berbagi hal disekitarnya dapat kita diskusikan dengan anak-anak, bertanya tentang yang ada dilingkungan sekitar, membicarakan perasaan, selain mengasah perkembangan bahasa, juga melatih anak untuk mengendalikan emosi.

f. Bermain peran Ajak lah anak melakukan suatu adegan seperti yang pernah alami.

\section{Prinsip Pengembangan Kecerdasan Interpersonal pada Anak Usia Dini}

Menurut teori Anderson, kecerdasan sosial ini mempunyai tiga dimensi utama yaitu a) social sensitivity (sensitivitas sosial), kemampuan anak untuk mampu merasakan dan mengamati reaksi-reaksi atau perubahan orang lain yang ditunjukkannya biak secara verbal maupun non-verbal. Anak yang memiliki

\footnotetext{
${ }^{61}$ Arrofa Acesta, Kecerdasan Kinestatik dan Interpersonal serta pengembannya, (Surabaya: Media Sahabat Cendekia, 2019), 17-18.
} 
sensitivitas sosial yang tinggi akan mudah memahami dan menyadari adanya reaksi- reaksi tertentu dari orang lain, entah reaksi tersebut positif ataupun negatif. b) Social insight (kemampuan anak untuk memahami dan mencari pemecahan masalah yang efektif dalam suatu interaksi sosial, sehingga masalah-masalah tersebut tidak menghambat apalagi menghancurkan relasi sosial yang telah dibangun anak, c) social communication adalah penguasaan keterampilan komunikasi sosial merupakan kemampuan individu untuk menggunakan proses komunikasi dalam menjalin danmembangun hubungan interpersonal yang sehat. ${ }^{62}$

Ketiga dimensi tersebut merupakan satu kesatuan yang utuh dan ketiganya saling mengisi satu sama lain sehingga jika salah satu dimensi timpang, maka akan melemahkan dimenasi yang lainnya. Kecerdasan interpersonal ini lebih bersifat cristalized menurut konsep yang dikemukakan oleh Cattel. ${ }^{63}$ Inteligensi cristalized dapat dipandang sebagai endapan pengalaman yang terjadi sewaktu inteligensi fluid bercampur dengan apa yang disebut inteligensi budaya. Inteligensi cristalized akan meningkat kadarnya dalam diri seseorang seiring dengan bertambahnya pengetahuan, pengalaman dan keterampilan-keterampilan yang dimilikioleh individu. Inteligensi fluid cenderung tidak berubah setelah usia 14 tahun atau 15 tahun, sedangkan inteligensi cristalized masih dapat terus berkembang sampai usia 30-40 tahun, bahkan lebih. Maka jelaslah bahwa kecerdasan interpersonal ini bersifat bisa berubah dan bisa ditingkatkan karena lebih merupakan proses belajar dari pengalaman anak sehari-hari bukan faktor hereditas. Semua anak bisa memiliki kecerdasan interpersonal yang tinggi, untuk itu anak membutuhkan bimbingan dan pengarahan baik dari orang tua maupun para pendidik dimana mereka bersekolah untuk mampu mengembangkan kecerdasan interpersonalnya.

Karakteristik anak yang memiliki kecerdasan interpersonal yang tinggi paling tidak dapat dilihat dari indikator berikut:

\footnotetext{
${ }^{62}$ Mike Anderson, The Development of Intelligence, (UK: Psychologycal Press, 1999), 87.

${ }^{63}$ Saifuddin Azwar, Pengantar Psikologi inteligensi, (Yogyakarta: Pustaka Pelajar, 2004),
} 33. 
a. Mampu mengembangkan dan menciptakan relasi sosial yang baru secara efektif;

b. Mampu berempati dengan orang lain atau memahami orang lain secara total;

c. Mampu mempertahankan relasi sosialnya secara efektif sehingga tidak musnah dimakan waktu dan senantiasa berkembang semakin intim, mendalam, dan penuh makna;

d. Mampu menyadari komunikasi verbal maupun non-verbal yang dimunculkan orang lain, atau dengan kata lain sensitif terhadap perubahan situasi sosial dan tuntutan-tuntutannya. Sehingga anak mampu menyesuaikan dirinya secara efektif dalam segala situasi;

e. Mampu memecahkan masalah yang terjadi dalam relasi sosialnya dengan pendekatan win-win solution, serta yang paling penting adalah mencegah masalah dalam relasi sosialnya.

f. Memiliki keterampilan komunikasi yang mencakup mendengarkan efektif, berbicara efektif dan menulis secara efektif. Termasuk di dalamnya mampu menampilkan penampilan fisik (model busana) yang sesuai dengan tuntutan lingkungan sosialnya.

Mereka yang memiliki kecerdasan interpersonal sangat memperhatikan orang lain, memiliki kepekaan yang tinggi terhadap ekspresi wajah, suara, dan gerak isyarat. Mereka juga mampu membedakan berbagai macam tanda interpersonal, seperti tanda kesedihan, isyarat di dengarkan, keinginan untuk di hargai. Individu yang cerdas dalam interpersonal juga memiliki kemampuan menanggapi secara efektif tanda interpersonalnya tersebut

dengan tindakan pragmatis tertentu, seperti mempengaruhi sekelompok orang untuk melakukan tindakan tertentu. Dengan kata lain kecerdasan interpersonal melibatkan banyak kecakapan, yakni kemampuan berempati kepada orang lain, kemampuan mengorganisasi sekelompok orang menuju suatu tujuan bersama, kemampuan mengenalidan membaca pikiran orang lain, kemampuan berteman atau menjalin kontak. ${ }^{64}$

${ }^{64}$ Tadkiroatun Musfiroh, Pengembangan Kecerdasan Majemuk, (Jakarta: Universitas, 2008), 73-74. 


\section{Metode Pengembangan kecerdasan Linguistic}

Kecerdasan interpersonal anak dapat dikembangkan melalui bermain. bermain adalah suatu kegiatan yang sangat menyenangkan bagi anak karena dengan bermain anak bisa mengekspresikan rasa bahagia dalam dirinya. Menurut Mulyasa ${ }^{65}$ bermain merupakan sesuatu kegiatan yang sangat penting dan tidak dapat dipisahkan dari setiap aktivitas anak usia dini.

Adapun kelebihan dari metode bermain peran adalah sebagai berikut :

1. Melibatkan anak secara aktif dalam pembelajaran yang di bangunnya sendiri

2. Memperoleh umpan balik yang cepat/segera

3. Memungkinkan siswa memperaktekan ketrampilan dalam komunikasi

4. Sangat menarik minat dan antusiasme anak

5. Membuat guru dapat mengajar pada ruang lingkup yang luas dalam mengoptimalkan kemampuan banyak anak pada waktu yang bersamaan

6. Mendukung anak untuk berfikir kritis dan analitis

7. Menciptakan percobaan dan situasi dan kehidupan dengan model lingkungan yang nyata. ${ }^{66}$

Sebagai keterampilan sosial, kecerdasan interpersonal anak dapat dikembangkan melalui berbagai pola. Pola-pola pengembangan kecerdasan interpersonal yang bisa dilakukan oleh orang tua maupun para pendidik adalah melalui pengembangan keterampilan sosial anak. Pola pengembangan keterampilan sosial tersebut diantaranya:

a. mengembangkan kesadaran diri anak

b. mengajarkan pemahaman situasi sosial dan etika sosial

c. mengajarkan pemecahan masalah efektif pada anak,

d. mengembangkan sikap empati pada anak,

e. mengembangkan sikap prososial pada anak,

f. mengajarkan berkomunikasi dengan santun pada anak,

g. mengajarkan cara mendengarkan efektif pada anak. ${ }^{67}$

\footnotetext{
${ }^{65}$ Mulyasa, Manajemen Pendidikan Anak Usia Dini, (Bandung : PT. Remaja Rosdakarya, 2012), 191.

${ }^{66}$ Mukhtar Latif, dkk., Pendidikan Anak Usia Dini, (Jakarta: Prenada Media Group. 2014), $10-17$.
} 


\section{KESIMPULAN}

Berdasarkan kajian pustaka yang telah peneliti lakukan, peneliti mendapatkan fakta bahwa multiple intelligences dapat dikembangkan melalui bermain dan pola asuh orang tua serta bimbingan guru dan teman sebaya pada anak usia dini. Masa golden age adalah masa yang tidak bisa diulang lagi. Masa ini juga sangat menentukan kehidupan seorang manusia kedepannya. Ketika belajar terdapat aspek yang mengalami perkembangan yakni, kognitif, berpikir abstrak, berpikir kreatif, sosial-emosional, motorik, bahasa atau komunikasi, dan dapat pula mengembangkan kreativitas. Sehingga dari aspek tersebut dapat meningkatkan perkembangan kecerdasan majemuk anak. Multiple Intelligences meliputi verballinguistik, logis- matematis, visual spasial, musikal, kinetik, intrapersonal, interpersonal, naturalis dan eksistensial. Multiple Intelligence pada aspek kecerdasan linguistik (Linguistic Intelligence) dan kecerdasan Interpersonal (Interpersonal Intellegence) sangat penting dikembangkan pada anak usia dini, karena menjadi jembatan dalam mengembangkan kecerdasan anak, pengembangan kecerdasan linguistik memberikan keterampilan berkomunikasi dan bersosialisasi serta mengekspresikan diri anak ke dunia luar, sedangkan kecerdasan Interpersonal memberikan kemampuan mengelola emosionalsosialnya sehingga menjadi kontroler bagi anak dalam berfikir dan bertindak menuju kedewasaan.

\section{DAFTAR PUSTAKA}

Acesta, Arrofa. Kecerdasan Kinestatik dan Interpersonal serta pengembannya, Surabaya: Media Sahabat Cendekia, 2019.

Afif, Ahmad. Psikologi Guru. Makassar: Alauddin University Press. 2014.

Amstrong, T. Setiap Anak Cerdas: Panduan Membantu Anak Belajar dengan Memanfaatkan Multiple Intelligence-nya, terj. Rina Buntaran, Jakarta: Gramedia Pustaka Utama. 2002.

\footnotetext{
${ }^{67}$ Safaria T., Interpersonal Intelligence, (Yogyakarta: Amara Books, 2005).
} 
Amstrong T. In Their Own Way: Discovering and Encouraging Your Child's Multiple Intelligences. Jakarta: PT Gramedia Pustaka Utama. 2003.

Andrea T. Raharjo. Hubungan antara Multiple intelligence dengan prestasi belajar siswa kelas XI di SMA Negeri 10 Malang. Jurnal Psikologi, Vol. 05 No. 1. 2010.

Asri Budiningsih, C. Belajar dan Pembelajaran. Jakarta: Rineka Cipta. 2012.

Azwar, Saifuddin. Pengantar Psikologi inteligensi. Yogyakarta: Pustaka Pelajar. 2004.

Chatib, Munif dan Said, Alamsyah. Sekolah Anak-Anak Juara: Berbasis Kecerdasan Jamak dan Pendidikan Berkeadilan, Bandung: Kaifa. 2012.

Dalton. Creative Thinking and Cooperative Talk in Small Group, Australia: Thomas Nelson, 1990.

Fitria. Kecerdasan majemuk (Multiple Intellegence) anak usia dini menurut Howard Gardner dalam perspektif pendidikan islam. Journal of Early Chilhood Islamic Education. Vol.3, No. 1. 2020.

Fridani, Lara. Inspiring Education Pendidikan Anak Usia Dini, Jakarta: PT. Elex Media Komputindo. 2009.

Gardner H. Multiple Intelligences: The theory in practice. New York: Basics Book. 2003.

Hamzah B. Uno dan Masri Kuadrat Umar. Mengelola Kecerdasan dalam Pembelajaran; Sebuah Konsep Pembelajran Berbasis Kecerdasan. Jakarta: Bumi Aksara. 2009.

Hasnida. Analisis Kebutuhan Anak Usia Dini, Jakarta: PT. Luxiama Metro Media. 2014.

Jasmine, Julia. Panduan Praktis Mengajar Berbasis Kecerdasan Majemuk Cet. I; Bandung: Nuansa, 2007.

Jasmine, Julia. Metode Mengajar Mutiple Intellegences. Bandung: Nuansa. 2016.

Kadek Suarca, Soetjiningsih dan Iga Endah Ardjana. Kecerdasan Majemuk pada Anak. Jurnal Sari Pediatri, Vol. 07, No. 2. 2005.

Khadijah, Media Pembelajaran Anak Usia Dini. Medan: Perdana Publishing. 2015. 
Lunenburg, Fred. Applying Multiple Intelligences in The Classroom: AFresh Look at Teaching Writing. International Journal of Scholary Academic Intellectual Diversity, vol. 16, No. 1. 2014.

Mansur, Pendidikan Anak Usia Dini dalam Islam, Yogyakarta: Pustaka Pelajar, 2014.

Mukhtar Latif, dkk. Pendidikan Anak Usia Dini. Jakarta : Prenada Media Group, 2014.

Mulyasa. Manajemen Pendidikan Anak Usia Dini. Bandung : PT. Remaja Rosdakarya. 2012.

Musfiroh, Tadkiroatun, Pengembangan Kecerdasan Majemuk, Jakarta: Universitas. 2008.

Mustaqim, Psikologi Pendidikan, Semarang: Fakultas Tarbiyah 1AIN Walisongo. 2004.

Nurani Sujiono, Yuliani. Konsep Pendidikan Anak Usia Dini. Jakarta: Indeks, 2012.

Nurul H Rofiah. Menerapkan Multiple Intellegences dalam Pembelajaran di Sekolah Dasar. Jurnal Dinamika Pendidikan Dasar. Vol. 08. No. 1. 2016.

Prasetyo, Justinus Reza, \& Yeni Andriani. Multiply Your Multiple Intelligences: Melatih 8 Kecerdasan Majemuk pada Anak Dan Dewasa. Yogyakarta: C.V Andi Offset. 2009.

Safaria, T. Pengembangan Multiple Intelligences Melalui Kegiatan NonIntrakurikuler dalam Rangka Meningkatkan Mutu Proses dan Hasil Pembelajaran, Jurnal Ekonomi \& Pendidikan, Vol. 5, No. 2. 2005.

Siswanto, Igrea dan Lestari, Sri. Panduan Bagi Guru dan Orangtua Pembelajaran Atraktif dan 100 Permainan Kreatif untuk PAUD, Yogyakarta: Andi, 2012.

Sri Widayati, dan Utami Widijati. Mengoptimalkan 9 Zona Kecerdasan Majemuk Anak. Yogyakarta: Luna Publisher, 2008.

Sumiyati, Konsep Dasar Pendidikan Anak Usia Dini dalam Islam, Yogyakarta: Cakrawala Institute, 2014.

Suparno, Paul. Teori Intelligence Ganda dan Aplikasinya di Sekolah, Cara Menerapkan Teori Multiple Intelligencess Howard Gardner. Cet. II; Yogyakarta: Kanisius, 2004. 
133 | MUSA WA, Vol. 13 No.1 Juni 2021 : 106-133

Syaodih, Nana Sukmadinata. Landasan Psikologi Proses Pendidikan. Bandung: PT Remaja Rosdakarya. 2011.

Trianto. Desain Pengembangan Pembelajaran Tematik Bagi Anak Usia Dini TK/RA \& Anak Kelas Awal SD/MI, Jakarta: Kencana, 2011.

Yaumi, Muhammad dan Nurdin Ibrahim. Pembelajaran Berbasis Kecerdasan Jamak (Multiple Intelligences) Mengidentifikasi dan Mengembangkan Multitalenta Anak. Jakarta: Prenadamedia Group, 2016.

Yuliani Nurani S, dkk. Bermain Kreatif Berbasis Kecerdasan Jamak, Jakarta: PT.Indeks, 2010.

Wardhani, Galuh dkk. Metode Pembelajaran Fisika Berdasarkan Teori Multiple Intelligences pada Materi Perpindahan Kalor. Jurnal Radiasi, vol. 6, No. 1, 2015.

Wiryokusumo, Iskandar. Dasar-Dasar Pengembangan Kurikulum. Jakarta: Bumi Aksara, 2011. 